\title{
Against the "Moonlight and Magnolia" myth of the American South. A new materialist approach to the dissonant heritage of slavery in the US: The case of Whitney Plantation in Wallace, LA
}

\author{
Dorota Golańska
}

Dorota Golańska, PhD

Associate Professor

University of Lodz

Faculty of Philology

Department of Cultural Research

Poland

e-mail dorota.golanska@uni.lodz.pl

Muzeológia a kultúrne dedičstvo, 2020, 8:4:137-160

DOI: $10.46284 / \mathrm{mkd} .2020 .8 .4 .9$

Against the "Moonlight and Magnolia" myth of the American South. A new materialist approach to the dissonant heritage of slavery in the US: The case of Whitney Plantation in Wallace, LA

The article presents an analysis of the operations of the Whitney Plantation Museum, which opened in 2014 in Wallace, LA (USA), situated within the context of plantation heritage tourism in the American South. The argumentation offers an illustration of the significant transition, even though still of marginal character, of the dominant tendencies of representing slavery in heritage sites (plantation museums) devoted to cultivating knowledge about the history of the region. New materialist in its orientation, the analysis subscribes to the most fundamental assumption of this philosophical tendency, namely that knowledge is generated in material-semiotic ways, and applies this approach in an enquiry into the educational experience offered to visitors by this heritage site. The article argues that although the emergence of institutions such as Whitney Plantation is meant to pluralise the memorial landscape of a given community, rather than serving as multivocal spaces they tend to remain steeped in fragmentation.

Keywords: Dissonant heritage; slavery; plantation tourism; Whitney Plantation Museum; new materialism

\section{Dissonant heritage: an introduction}

Contemporary societies, in Macdonald's words, have become "obsessed with the disappearance of collective memory and its preservation" - a tendency that sits at the origin of the erection of diverse heritage sites "designed to remind us of histories that might otherwise be lost". ${ }^{1}$ At the same time, the institutionalised memorial narratives (embodied in and propagated by museums, memory sites, educational institutions, etc.) tend to offer already interpreted versions of the past, often avoiding difficult or shameful tropes of history, silencing or belittling them. Hence, although current practices of memorialisation are predominantly related to the commemoration of collective traumas (such as genocide, torture, exploitation, catastrophes, massive killings, or violence), there is a discernible tendency to circumvent those traumatic stories which do not fit within the dominant authoritative narrative of the nation's history or in which the representatives of a given nation played the role of perpetrators of a crime. The sense of history of a community depends heavily on the available interpretive frameworks shaping the ways people tend to think about the past and its meanings. It is therefore of crucial importance to examine the hegemonic discourses pervading the processes of memory cultivation, both in reference to what societies struggle to remember and what

${ }^{1}$ MACDONALD, Sharon. Memorylands. Heritage and Identity in Europe Today. New York: Routledge, 2013 , p. 1. 
D. Golańska: Against the "Moonlight and Magnolia" myth of the American South...

they choose to forget. ${ }^{2}$ Heritage sites serve as important, although selective, vehicles for historical remembrance. ${ }^{3}$ They also play pivotal roles in producing knowledge about the socalled "difficult past", "undesirable heritage", "dissonant heritage" or "heritage that hurts". These labels are meant to signal "a heritage that the majority of the population would prefer not to have" 5 and are connected to what is often referred to in terms of "national" or "cultural" traumas. ${ }^{6}$ Certainly, memory is far from being value-neutral ${ }^{7}$ and, as Turnbridge and Ashworth argue, heritage must be seen as inherently dissonant - a contentious realm populated with group identities, interests and incompatible versions of history. ${ }^{8}$ Although typically perceived as belonging to the past, heritage has to adapt to the different social and geographical demands of the present. The ways the difficult, or shameful, past is dealt with within the official memorial discourses produced in connection with material arrangements at heritage sites are therefore worth exploring, as the interpretations of the past these sites convey speak volumes about the current social tensions, revealing the problematic divisions of contemporary communities.

The official narrative about the role of slavery in the development of the US has held sway for over a century. The crucial function of the slaves to the operation of plantations in the mythic American South has until recently been either not included in the narratives offered to tourists visiting the heritage sites or presented as insignificant and of marginal importance. ${ }^{9}$ As Du Bois noted in 1935,

\footnotetext{
${ }^{2}$ See: BRUNDAGE, Fitzhugh W. The Southern Past: A Clash of Race and Memory. Cambridge, MA: Harvard University Press, 2006.

${ }^{3}$ For elaboration of notions of collective memory and memory as a cultural system, see, for instance, HALBWACHS, Maurice. On Collective Memory. Chicago, IL: University of Chicago Press, 1992 or SCHWARTZ, Barry. Memory as a Cultural System: Abraham Lincoln and World War II. In: American Sociological Review, vol. 61, 1992, no. 5, p. $908-927$. ${ }^{4}$ The term "difficult past" was coined by William Logan and Keir Reeves (see: LOGAN, William, REEVES, Keir. Introduction: Remembering Places of Pain and Shame. In: LOGAN, William (ed). Places of Pain and Shame: Dealing with "Difficult Heritage". London: Routledge, 2009, p. 1-14); the term "undesirable heritage" was used by Sharon Macdonald (see: MACDONALD, Sharon. Undesirable Heritage: Fascist Material Culture and Historical Consciousness in Nuremberg. In: International Journal of Heritage Studies, vol. 12, 2006, no. 1, p. 9-28); the term "dissonant heritage" was offered by Tunbridge and Ashworth (see: TUNBRIDGE, J. E., ASHWORTH, G. J. Dissonant Heritage. The Management of the Past as a Resource in Conflict. Chichester: Wiley, 1996), and the term "heritage that hurts" was used by Uzzell and Balantyne (see: UZZELL, David L., BALLANTYNE, Roy. Heritage that Hurts: Interpretation in a Postmodern World. In: UZZELL, David L., BALLANTYNE, Roy (eds). Contemporary Issues in Heritage and Environmental Interpretation. London: The Stationery Office, 1998, p. 152-171). For elaboration of similar ideas see: ALONSO, Anam M. The Effects of Truth: Representation of the Past and the Imagining of Community. In: Journal of Historical Sociology, vol. 1, 1988, no. 1, p. 33-58; OOI, Ceng-Seng. Persuasive Histories: Decentring, Recentring and the Emotional Crafting of the Past. In: Journal of Organizational Change, vol. 15, 2002 , no. 6, p. 606-620; VINITZKY-SEROUSSI, Vered. Commemorating and Difficult Past: Yitzhak Rabin's Memorials. In: American Sociological Review, vol. 67, 2002, no. 1, p. 30-52 and WAGNER-PACIFICI, R., SCHWARTZ, Barry. The Vietnam Veterans Memorial: Commemorating a Difficult Past. In: American Journal of Sociology, vol. 97, 1991, no. 2, p. 376-420).

${ }^{5}$ MACDONALD, Sharon. Undesirable Heritage... p. 9.

${ }^{6}$ See: NEAL, Arthur G. National Trauma and Collective Memory. Armonk: M.E. Sharpe, 1998.

${ }^{7}$ See: GREENE, Mark A. The Messy Business of Remembering: History, Memory, and Archives. In: Archival Issues, vol. 28, no. 2, 2003-2004, p. 95-103.

${ }^{8}$ TUNBRIDGE, J. E., ASHWORTH, G. J. Dissonant Heritage... p. 21.

${ }^{9}$ For exploration of this issue see: BUTLER, David L. Whitewashing Plantations: The Commodification and Social Creation of a Slave-free Antebellum South. In: International Journal of Hospitality, vol. 2, no. 3/4, 2001, p. $159-171$ and EICHSTEDT, Jennifer, SMALL, Stephen. Representations of Slavery: Race and Ideology in Southern Plantation Museums. Washington, DC: Smithsonian Institute Press, 2002.
} 
the facts of American history have in the last half century been falsified because the nation was ashamed. The South was ashamed because it fought to perpetuate slavery. The North was ashamed because it had to call in the black men to save the Union, abolish slavery and establish democracy. ${ }^{10}$

This shame has led to major distortions of the official hegemonic narratives of US history and translated into strategies of negligence, or intentional marginalisation, of those memorial discourses that run counter to the formal (although fallacious) historical knowledge. Slavery, a state-supported system of violence and oppression, has not been officially remembered. This is due to the fact that the memory of this difficult past has been, as Modlin underlines, especially prone to dissonance, ${ }^{11}$ as well as being characterised by tensions and uncomfortable interactions between visitors, academicians and operators of heritage sites. This dissonance is, as Dann and Seaton reveal, a result of the fact that cultural discourses tend to shape the past into cleansed national legacies, within which the history of the enslavement of Blacks simply does not fit. ${ }^{12}$ Recently, things seem to have slightly changed, which is visible in the establishment of at least three major institutions: the Whitney Plantation Museum in Wallace, LA (2014); the Smithsonian National Museum of African American History and Culture (2016) in Washington, DC; and the Lynching Memorial in Montgomery, AL (2018). The three heritage sites offer a radically different perspective on the shameful past of slavery in the US, looking at these problematic events from the point of view of African Americans, thus challenging the hitherto well-established narratives on how (or whether) the system of enslavement should be memorialised. This might signal a salient shift in paradigms of representing the history of slavery as a difficult component of national heritage. Certain modifications introduced within the past twenty years into the dominant discourse about the historical experiences of the enslaved offered at plantation heritage sites in the American South have also been documented, although evidence of these changes is still rather scarce. ${ }^{13}$

Taking a new materialist perspective, this article analyses operations of the Whitney Plantation in Wallace, LA. It is based on an ethnographic study conducted by the author on site in April 2015. Observation and qualitative methods were used as the primary means of investigation. Observation is here understood as a very complex and demanding process, which is not limited to sight, but rather includes joint, synaesthetic operations of touch, smell, hearing and seeing, and translating these sensations into complex embodied experiences and feelings. Obviously, these experiences are profoundly shaped by the researcher's previous knowledge and personal archives of memory. This approach necessarily includes a critical self-reflexive awareness and analysis of how these past experiences structure what is being researched and how they shape the formulation of conclusions. The article presents the outcomes of the fieldwork study that was thusly undertaken.

\footnotetext{
${ }^{10}$ DU BOIS, W. E. Burghardt. Black Reconstruction: An Essay Toward a History of the Part Which Black Folk Played in the Attempt to Reconstruct Democracy in America, 1860-1880. Oxford: Oxford University Press, 1935/2014, p. 117.

${ }^{11}$ MODLIN, Arnold E. Tales Told on the Tour: Mythic Representations of Slavery by Docents at North Carolina Plantation Museums. In: Southeastern Geographer, vol. 48, no. 3, 2008, p. 265-287.

${ }^{12}$ DANN, Graham M.S., SEATON, A.V. Slavery, Contested Heritage and Thanatourism. In: International Journal of Hospitality \& Tourism Administration, vol. 2, no. 3/4, 2001, p. 1-2.

${ }^{13}$ ALDERMAN, Derek H., BUTLER, David L., HANNA, Stephen P. Memory, Slavery, and Plantation Museums: The River Road Project. In: Journal of Heritage Tourism, vol. 11, no. 3, 2015, p. 209-218.
} 
My analysis offers an illustration of the significant transition, still of marginal character, of the dominant tendencies of representing slavery in heritage sites (Southern plantation museums). Whitney Plantation is committed to presenting "accurate historical tours touching on the culture, life and operations of New Orleans plantations, along with the history behind the Atlantic Slave Trade". ${ }^{14}$ This is a part of larger tendency discernible in memory culture toward offering a more contested (multivocal) or fragmented ${ }^{15}$ panorama of "tangled memories", ${ }^{16}$ creating space for new, often subversive, ways of interpreting the past and pluralising the mnemonic landscape of a given community. This is achieved through a variety of means applied at contemporary heritage sites, from symbolic and discursive display strategies, through the emotional punctuation of employed historical narratives and production of empathetic identifications, to more affective or bodily techniques of generating knowledge. A closer look at their sensorial material dimension (which combines with their narrative and symbolic facets) sheds an altogether different light on heritage sites. This lets us more fully comprehend their "material-semiotic" nature and how they productively assemble this with the (bodies of) visitors. As I want to make clear, it is not enough to approach such sites by looking exclusively at their discursive workings. Arguing in a new materialist spirit, the symbolic (or semiotic) dimension would not be operative without the material aspects that sustain and make meanings possible in the first place. As Boivin ${ }^{18}$ underlines, the material facets of the place not only provide a medium through which social values become encoded and transmitted, but also act as significant agents enabling understanding and provoking feeling through both their physical features and the ways in which visitors engage with and use these features. My aim is to put emphasis on the aesthetic operations of the analysed heritage site. And, as I underline, the aesthetic must be understood in terms of material-semiotic encounters.

This article takes a supply-oriented approach to the analysis of the Whitney Plantation Museum, with an aim to contrast this memorial site with the well-established ways of representing regional heritage adopted by plantation museums in American South. Recently, the volume of scholarship exploring the experiences and demands of visitors to the plantation museums (that is, demand-oriented research) has been growing, but this article focuses on the design of the place, the use of the landscape and artefacts, in creating a specific perspective on the history of slavery and the experiences of the enslaved. The analysis subscribes to the most fundamental assumption of philosophical new materialism, namely that knowledge is generated in material-semiotic ways. Even though the extant scholarship clearly acknowledges the importance of material place, landscape, and artefacts for the creation of a desired narrative to be presented in heritage sites, as well as underlining the significance of the experience of moving from one place to another during the tour, the analysis of the tangled operations of plantation heritage sites from an explicitly new materialist perspective has not yet been undertaken. This article aims at partly closing this gap.

\footnotetext{
${ }^{14}$ Whitney Plantation, accessed 23 November 2020, www.whitneyplantation.org.

15 See: VINITZKY-SEROUSSI, Vered. Commemorating and Difficult Past... and WAGNER-PACIFICI, R., SCHWARTZ, Barry. The Vietnam Veterans Memorial...

${ }^{16}$ STURKEN, Marita. Tangled Memories. Berkeley, CA: University of California Press, 1997.

${ }^{17}$ HARAWAY, Donna. Situated Knowledges. The Science Question in Feminism and the Privilege of Partial Perspective. In: Feminist Studies, vol. 14, no. 3, 1988, p. 575-599.

${ }^{18}$ See: BOIVIN, Nicole. Material Cultures, Material Minds: The Impact of Things on Human Thought, Society, and Evolution. Cambridge: Cambridge University Press, 2008.
} 


\section{Remembering slavery in the American South: the background}

The South has a unique place in the popular American imagery and mythology. It has been romanticised and rendered nostalgic through the evocation of the "moonlight and magnolia" myth of idyllic countryside. Taking the form of selective amnesia, Southern nostalgia is translated into a systematic and deliberate negligence toward the gloomy misery and horrendous violence connected to the institution of slavery, so deeply inscribed in the history of this region. Even though the existence of the enslaved could not be omitted in the romanticised representations of the American South's past, slavery has been typically marginalised and trivialised, while the dominant marketed representations of black subservience have had very little in common with the harsh conditions and experiences the enslaved had to endure. This nostalgic portrayal of the American South spreads from novels, through advertising media, to films, ${ }^{19}$ perpetuating the dominant "narrative economy" 20 of the benevolent white masters and their happy black servants. ${ }^{21}$ As McPherson proves, such a nostalgic view of the American South, with plantations central to the region's development and wealth, is only possible through a purposeful collective act of disremembering or misremembering the region's deeply racialised past. ${ }^{22}$

The contentious legacy of slavery makes the history of the South profoundly problematic. As such, Southern heritage sites constitute a favourable location for studying racialisation processes, as they tend to reproduce the dominant racial identities, histories and discourses as well as perpetuate inequalities and discriminatory practices. ${ }^{23}$ The plantation occupies a privileged place in the memorial landscape of the American South and, as Adams proposes, it plays a seminal role in shaping the official interpretations of Southern history and the understanding of the nature of race relations during the antebellum period. ${ }^{24}$ As Dann and Seaton elaborate, the former plantations, to which the genesis of racial oppression in the US should be traced, have been rearticulated as heritage sites and count as important mnemonic

\footnotetext{
${ }^{19}$ See, for instance, such works as: YUHL, Stephanie E. A Golden Haze of Memory: The Making of Historic Charleston. Chapel Hill, NC: University of North Carolina Press, 2005 or THOMPSON, Craig, TIAN, Kelly. Reconstructing the South: How Commercial Myth Compete for Identity Value Through the Ideological Shaping of Popular Memories and Counter-Memories. In: Journal of Consumer Research, vol. 34, no. 5, 2008, p. 595-613. Hoelscher, for instance, traces the origins of idealising Southern plantations to the period of the 1880s, when white inhabitants of the South tended to glorify the social life before the Civil Wars as a strategy of dealing with ongoing debates in the region regarding the problem of meaning of freedom for Blacks (see: HOELSCHER, Steven. The White-Pillared Past: Landscapes of Memory and Race in the American South. In: SCHEIN, Richard (ed). Landscape and Race in the United States. New York: Routledge, 2006, p. 46). As Hoelscher proposes, the paternalistic depiction of slavery as a benign institution connecting good masters and faithful slaves is an essential part of the mythology of the Old South that has been traditionally used by Whites to justify racial inequalities (see: HOELSCHER, Steven. Making Place, making Race: Performances of Whiteness in the Jim Crow South. In: Annals of the Association of American Geographers, vol. 93, no. 3, 2003, p. 657-686).

${ }^{20}$ CARTER, Perry L., BUTLER, David L., ALDERMAN, Derek, H. The House the Story Built: The Place of Slavery in Plantation Museum Narratives. In: The Professional Geographer, vol. 66, no. 4, 2014, p. 547-557.

${ }^{21}$ See: SUNDQUIST, Eric J. To Wake the Nation: Race in the Making of American Literature. Cambridge, MA: Harvard University Press, 1993.

${ }^{22}$ MCPHERSON, Tara. Reconstructing Dixie: Race, Gender, and Nostalgia in the Imagined South. Durham, NC: Duke University Press, 2003.

${ }^{23}$ For elaboration of these issues, see: INWOOD, Joshua F.J. Sweet Auburn: Constructing Atlanta's Auburn Avenue as a Heritage Tourist Destination. In: Urban Geography, vol. 31, no. 5, 2010, p. 573-594 and ZAKOS, Katharine P. Truth is Marching On: The Lasershow Spectacular at the Stone Mountain Park Confederate Memorial and the Changing Narratives of History. In: Journal of Heritage Tourism, vol. 10, no. 3, 2015, p. 280-295.

${ }^{24}$ ADAMS, Jessica. Local Color. The Southern Plantation in Popular Culture. In: Cultural Critiques, vol. 42, 1999, p. 163-187.
} 
D. Golańska: Against the "Moonlight and Magnolia" myth of the American South...

places, dominating the current tourist landscape of the South. ${ }^{25}$ The region is dotted with plantation museums, framed as primary tourist attractions. Currently there are close to 400 such destinations open for tours within the US, predominantly located in North Carolina, Louisiana, Georgia, Virginia and South Carolina. Sadly, most of these heritage sites offer a very whitecentric view of what life on the plantation looked like, focusing on the family of the owners and their possessions, while ignoring the crucial contribution of the enslaved to the construction and maintenance of the plantation houses, as well as to the production of the wealth enjoyed by the master's family. The dominant narratives play an important role in generating and legitimising knowledge of who is considered historically important for the particular place or region, as well as, by omission, whose historical contributions do not matter. Given the racial bias of these discourses, these sites participate in creating a particular view of the shameful history, translating into observable social injustices and practices of exclusion. The latter are manifest in, among other things, a tacit denial of the heritage claims of African Americans. The prevailing strategies of constructing history in most of the Southern plantation museums endeavour to create a distorted, inaccurate image of the past, dispossessing African Americans of their own legacy. ${ }^{26}$ In Buzinde and Santos' words, these representational inequalities "not only annihilate the histories of marginalised groups from the official heritage narrative but also foster feelings of disinheritance and exasperate historical and contemporary issues of racism". ${ }^{27}$ In a similar vein, Giovanetti underlines that the plantation serves as "a defining space for racial meaning and for the racial experiences of those who lived in it and those who live its legacy in the present". ${ }^{28}$ As Alderman and Inwood notice, "the traditional neglect of African Americans within US collective memory has reflected and worked to justify a larger racial inequality in American life still felt far beyond memorials and monuments". ${ }^{29}$

Bearing in mind the increasing preoccupation with issues of public memory, the fact that interest in research on the legacies of enslavement has been growing should come as no surprise. These academic efforts explore the dominant discourses and material or performative strategies employed by the plantation owners, docents, managers and guides, as well as tourist expectations and preferences regarding the inclusion of the issue of slavery in plantation tours. ${ }^{30}$

${ }^{25}$ DANN, Graham M.S., SEATON, A.V. Slavery, Contested Heritage and Thanatourism...

${ }^{26}$ BUZINDE, Christine N., SANTOS, Carla A. Interpreting Slavery Tourism. In: Annals of Tourism Research, vol. 36, no. 3, 2009, p. 439-458.

${ }^{27}$ BUZINDE, Christine N., SANTOS, Carla A. Interpreting Slavery Tourism... p. 484.

${ }^{28}$ GIOVANETTI, Jorge L. Grounds of Race: Slavery, Racism and the Plantation in the Caribbean. In: Latin American and Caribbean Ethnic Studies, vol. 1, no. 1, 2006, p. 5.

${ }^{29}$ ALDERMAN, Derek H., INWOOD, Joshua F. Landscapes of Memory and Socially Just Futures. In: SCHEIN, Richard, WINDERS, Jamie, JOHNSON, Juala (eds). A New Companion to Cultural Geography. Chichester: Wiley Blackwell, 2013, p. 194.

${ }^{30}$ Recently, the volume of scholarly work exploring these topics has been growing. See, for instance: ALDERMAN, Derek H., BUTLER, David L., HANNA, Stephen P. Memory, Slavery, and Plantation Museums: The River Road Project. In: Journal of Heritage Tourism, vol. 11, no. 3, 2015, p. 209-218; ALDERMAN, Derek H., MODLIN, E. Arnold. (In)visibility of the Enslaved Within Online Plantation Tourism Marketing: A Textual Analysis of North Carolina Websites. In: Journal of Travel and Tourism Marketing, vol. 25, no. 3-4, 2008, p. 265-281; ALDERMAN, Derek H., MODLIN, E. Arnold. Southern Hospitality and the Politics of African American Belonging: An Analysis of North Carolina Tourism Brochure Photographs. In: Journal of Cultural Geography, vol. 30, no. 1, 2013, p. 6-31; ALDERMAN, Derek H., MODLIN E. Arnold. On the Political Utterances of Plantation Tourists: Vocalizing the Memory of Slavery on River Road. In: Journal of Heritage Tourism, vol. 11, no. 3, 2015, p. 275-289; BENJAMIN, Stephanie, ALDERMAN, Derek H. Performing a Different Narrative: Museum Theatre and the Memory-work of Producing and Managing Slavery Heritage at Southern Plantation Museums. In: International Journal of Heritage 
Most of this research confirms the findings of Eichstedt and Small, published in 2002 in their seminal book entitled Representations of Slavery: Race and Ideology in Southern Plantation Museums. ${ }^{31}$ The two scholars, after studying the tourist offer of 122 plantation museums located in the American South, identified four main strategies through which the sites deal with the history of slavery and the contribution of the enslaved to the life of the Southern plantation as well as of the region in general. The majority of the studied sites $(56 \%)$ perform "symbolic annihilation" consisting of the practical erasure of enslavement from the narratives of the offered tours, which focus exclusively on the owner's family and the architectural details of the mansion. Another 27\% use "trivialisation and deflection", representing slaves as grateful servants to their morally upright and generous masters. In these cases, although the African American story is woven into the dominant narrative, a denigrating picture of the contribution of Blacks to the life of the plantation is offered. Another group of sites (4\%) uses "segregation" strategies, by relegating the issue of slavery and the experience of the enslaved to separate locations or tours, so that the two histories are presented as mutually exclusive or unrelated. Only about $3 \%$ of the examined sites adopt a method of "relative incorporation", referring to the issue of slavery throughout the tour. Such an interpretative strategy embraces an inclusive perspective and is "much more likely to raise issues that disturb a positive construction of whiteness". ${ }^{32}$ The research evidenced the tremendous dominance of the master-centred narrative and a tendency to ignore or romanticise the experiences of the enslaved, or what Butler calls a "whitewashing" of the history of the South. ${ }^{33}$ This is achieved through a variety of means - narrative, material and performative. Even though the idea of presenting the heritage of slavery from the point of view of the enslaved is still very much an exception, recent research has demonstrated

Studies, vol. 24, no. 3, 2018, p. 270-282; BEST, Mechelle N., PHULGENCE, Winston F. Interpretation of Contested Heritage at an Attraction in St. Lucia. In: Journal of Heritage Tourism, vol. 8, no. 1, 2013, p. 21-35; BUTLER, David L. Whitewashing Plantations: The Commodification and Social Creation of a Slave-free Antebellum South. In: International Journal of Hospitality, vol. 2, no. 3/4, 2001, p. 159-171; BUZINDE, Christine N. Discursive Construction of the Plantation Past within a Travel Guidebook. In: Journal of Heritage Tourism, vol. 5, no. 3, 2010, p. 219-235; DANN, Graham M.S., POTTER, Robert B. Supplanting the Planters: Hawking Heritage in Barbados. In International Journal of Hospitality \& Tourism Administration, vol. 2, no. 3/4, 2001, p. 51-84; DAVIS, Patricia. Memoryscapes in Transition: Black History Museum, New South Narratives, and Urban Regeneration. In: Southern Communication Journal, vol. 78, no. 2, 2013, p. 107-127; DENNIS, Benjamin G., DENNIS, Anita K. Slaves to Racism: An Unbroken Chain from America to Liberia. New York: Algora Publishing, 2008; FORBES, Candace, ALDERMAN, Derek H., BUTLER, David L. Tourist Plantation Owners and Slavery: A Complex Relationship. In: Current Issues in Tourism, vol. 21, no. 15, 2018, p. 1743-1760; HANDLER, Richard, GABLE, Eric. The New History in an Old Museum: Creating the Past at Colonial Williamsburg. Durham, NC and London: Duke University Press, 1997; JACKSON, Antoinette T. Shattering Slave Life Portrayals: Uncovering Subjugated Knowledge in US Plantation Sites in South Carolina and Florida. In: American Anthropologist, vol. 113, no. 3, 2011, p. 448-462; JACKSON, Antoinette T. Speaking for the Enslaved: Heritage Interpretation at Antebellum Plantation Sites. New York: Routledge, 2016; MODLIN, Arnold. E., ALDERMAN, Derek H., GENTRY, Glenn W. Tour Guides as Creators of Empathy: The Role of Affective Inequality in Marginalizing the Enslaved at Plantation House Museums. In: Tourist Studies, vol. 11, no. 1, 2011, p. 3-19; POIROT, Kristan, WATSON, Shevaun E. Memories of Freedom and White Resilience: Place, Tourism, and Urban Slavery. In: Rhetoric Society Quarterly, vol. 45, no. 2, 2015, p. 91-116; SMALL, Stephen. Still Back of the Big House: Slave Cabins and Slavery in Southern Heritage Tourism. In: Tourism Geographies, vol. 15, no. 3, 2013, p. 405423; YANKHOLMES, Aaron, MCKERCHER, Bob. Rethinking Slavery Heritage Tourism. In: Journal of Heritage Tourism, vol. 10, no. 3, 2015, p. 233-247; YANKHOLMES, Aaron, MCKERCHER, Bob. Understanding Visitors to Slavery Heritage Sites in Ghana. In: Tourism Management, vol. 51, no. C, 2015, p. 22-32.

${ }^{31}$ EICHSTEDT, Jennifer, SMALL, Stephen. Representations of Slavery....

${ }^{32}$ EICHSTEDT, Jennifer, SMALL, Stephen. Representations of Slavery... p. 10-11.

${ }^{33}$ BUTLER, David L. Whitewashing Plantations... 
D. Golańska: Against the "Moonlight and Magnolia" myth of the American South...

that a "growing number of plantations are incorporating slavery into their depictions of the antebellum past". ${ }^{34}$ However, as Alderman, Butler and Hanna underline, "it would be unwise to characterise this as wholesale change". ${ }^{35}$ And even if the narratives about the enslaved get incorporated into the plantation tours, it does not mean they are free from stereotypical historical myths.

The fact that the history of the American South is in heritage sites depicted from a predominantly white perspective must be approached in the broader context of the racial construction of public memory, which embodies the preferences of powerful social groups as to what they want to remember and what they would like to forget. In that sense, as Buzinde and Osagie underline, we should not think of plantation museums as "innocent edifications", but rather as tangible incarnations of the dominant social values. The two scholars connect studies on the prevailing portrayal of the history of slavery in the US and the discussion of the racial politics of plantation museums to the issues of cultural citizenship, pointing to the fact of whose heritage counts as legitimate in the leading authoritative memorial narratives. ${ }^{36}$ The heritage industry is a location in which the dominant "racialised imagery and ideology" are sustained and perpetuated, "reinforcing the silences, stereotypes, and erasures in people's minds". ${ }^{37}$ Worth noticing is the fact that the national landscape of memory, typically controlled by the dominant social groups and powerful elites, ${ }^{38}$ embodies important tensions, translating into the sustenance of discriminatory practices (enacted on a symbolic level) and the perpetuation of social (or in this case, racial) inequalities. It does not mean, however, that the predominant landscape of memory is not contested. The marginalised groups tend to challenge the authoritative accounts spread by the memorial sites, offering counter-narratives and focusing on those aspects of the "factual" description of the history that have traditionally been omitted or belittled. There is an observable tendency for African Americans to reclaim their heritage by incorporating the issue of enslavement into the memorial landscape of the American South. Communities that are discriminated against struggle to use the same landscape that serves as a source of identification for the dominant groups to expose their own belonging, heritage and history. Consequently, the same scenery can potentially function within the different memorial narratives, being referred to by the representatives of different social (racial) groups as a basis for their collective identities. In what follows I will look at a plantation museum offering a slavecentric perspective and devoted to the presentation of the experiences of the enslaved. This goes counter to the dominant Southern historical discourses outlined above.

\section{A different perspective: the case study}

The Whitney Plantation, located on Louisiana's historic River Road in Wallace, LA, which is about a 40-minute drive from New Orleans, is owned by a (white) attorney, John Cummings. He originally bought this 1,700 acre property from a petrochemical company and since then has invested approximately $\$ 8$ million to turn the place into the first plantation museum offering

\footnotetext{
${ }^{34}$ ALDERMAN, Derek H., BUTLER, David L., HANNA, Stephen P. Memory, Slavery, and Plantation Museums... p. 3. ${ }_{35}$ ALDERMAN, Derek H., BUTLER, David L., HANNA, Stephen P. Memory, Slavery, and Plantation Museums... p. 3. ${ }^{36}$ BUZINDE, Christine N., OSAGIE, Iyunolu F. Slavery Heritage Representations, Cultural Citizenship, and Judicial Politics in America. In: Journal Historical Geography, vol. 39, 2011, p. 41-64.

${ }^{37}$ EICHSTEDT, Jennifer, SMALL, Stephen. Representations of Slavery... p. 3.

${ }^{38}$ See: FOREST, Benjamin, JOHNSON, Juliet. Unravelling the Threads of History: Soviet-Era Monuments and Post-Soviet National Identity in Moscow. In: Annals of the Association of American Geographers, vol. 92, no. 3, 2002, p. $524-547$.
} 
a narrative from the viewpoint of the enslaved. ${ }^{39}$ The owner was involved in developing the project (in cooperation with a Senegalese scholar, Ibrahima Seck) for 13 years before the place was opened to the public in 2014. ${ }^{40}$ This sugarcane plantation was home to over 350 African slaves, who were involved in the extremely demanding production of molasses. Even though the museum is situated on the former plantation and makes use of a number of its original artefacts and infrastructures, some of the buildings had to be brought to the site from other similar places to fully reconstruct - and make visitors feel bodily engaged in - the experience of the enslaved. These relics include slave cabins, a church and a steel cage from the 1800 s that served as a jail for mutinous or disobedient slaves.

This heritage site is meant to partly fill the void in the memorial landscape of the American South with regards to the fair and reliable representation of the experiences of the enslaved, challenging the whitened and romanticised accounts spread by other heritage sites in the region. Whitney Plantation functions both as a memorial and an educational site. It was designed to serve as a tribute to the lives of the enslaved and as an institution that offers a slave-centred perspective on enslavement as an institution constituting a necessary part of the history and economy of the American South. Even though it deals with a difficult past, the goal of the place is not to incite shame or resentment in visitors; rather, it is meant to do justice to what has not yet been adequately remembered and memorialised. Instead of using any entertainment techniques for producing knowledge about the past (such as costumes or staged performances, which are increasingly popular at a number of other Southern plantations), Whitney Plantation employs material-semiotic means of manufacturing an educational experience, drawing on the bodily-intellectual encounters of the visitors and the site/artefacts. Although similar strategies have also been incorporated into guided tours offered by other plantation museums, it seems that this site tells a completely different story, destabilising the dominant constructions and perceptions of the mythic American South embodied in the romanticised myth of "moonlight and magnolia". A new materialist perspective, preoccupied with the processes of generating knowledge, enables understanding of how the museum achieves this goal.

The tour offered to visitors to the Whitney Plantation combines symbolic and material means. This applies to both the way the story is presented (through employing a specific narrative and facilitating contact with material artefacts) and the ways in which visitors are encouraged to participate in the bodily-intellectual learning experience. In this sense, the intended design of the educational process rests on the idea of an "aesthetic encounter", ${ }^{11}$ where the site and

\footnotetext{
39 Another important plantation site situated across the Mississippi River at Natchez, LA, is Frogmore Cotton Plantation and Gins, which offers a meaningful experience of visiting slave cabins and a narrative on slave culture and customs. Rather than serving exclusively as a museum, the site is an operating plantation, which offers historical tours ("Cotton Then \& Now" and "The Plantation Civil War"). For more details, visit www.frogmoreplantation. com.

${ }^{40}$ See: AMSDEN, David. Building the First Slavery Museum in America. In: New York Times Magazine, 26 February 2015,http:// mobile.nytimes.com/2015/03/01/magazine/builitng-the-first-slave-museum-in-america.html, accessed 21 February 2020 and RIDER, Polly. A History of the Whitney Plantation, America's First Slavery Museum. In: The Culture Trip, December, 2019, https://theculturetrip.com/north-america/articles/whitney-plantationamerica-s-first-slavery-museum/, accessed 16 February 2020.

${ }^{41}$ For more detailed new materialist elaboration of the concept of "affective encounter" see GOLAŃSKA, Dorota. Affective Spaces, Sensuous Engagements: In Quest of A Synaesthetic Approach to "Dark Memorials". In: International Journal of Heritage Studies, vol. 21, no. 8, 2015, p. 773-790; GOLAŃSKA, Dorota. Terrifying Pleasures: In Quest of an Affirmative Approach to "Dark" Installation Art. In: Liminalities: A Journal of Performance Studies, vol. 12,
} 
the visitor affect and are affected by each other, and where knowledge emerges as a materialsemiotic assemblage.

The idea of "material-semiotic" 42 (or "material-discursive" 43 ) entanglement is dear to the new materialist ways of thinking. As a significant correction of the social constructivist paradigm, it assumes that representation is not the only thing that matters. Rather, we should acknowledge that matter is as active as our interpretative frameworks, and that matter makes mattering possible in the first place. Hence, it is necessary to do justice to the agential faculties of materiality (and matter), that is, to the element that has typically been crossed out from the dominant Western philosophical accounts. Barad, in a new materialist spirit, calls for recognition of "the agential contributions of all material forces (both 'social' and natural')" 44 to the processes of knowledge production. Also, new materialist ways of thinking have salient implications for the conceptualisation of learning procedures, enabling acknowledgement of the dispersed agential capacities of all actors involved in the educational material-semiotic experience, and deconstructing the traditional binaries between the subject and object of knowledge/learning. Such an understanding of educational procedures requires a bodily-intellectual involvement with the context in which the processes of thinking/feeling/knowing are situated; it also calls for recognition of different practices and relationalities that contribute to the emergence of knowledge. Accordingly, visitors to the plantation are not passive learners. Rather, they engage in an intense, bodily experience involving the physical materiality of the place. The material artefacts/landscape do not serve solely as inactive means or vehicles for the intended symbolic narratives, operating instead as active agents effectively structuring the processes of generating knowledge. In the remainder of this article, I will focus on four aspects of the profound material-semiotic educational experience offered to the visitors at Whitney Plantation, looking at the landscape, the inhabitants, the violence and the context of the transatlantic slave trade, evoked as powerful tropes of the on-site learning process.

\section{The landscape}

Certainly, the physical environment and the movement of bodies in space are crucial to the procedure of knowledge production in heritage places, where, as Modlin, Alderman and Gentry observe, "retelling the past happens in and through places and landscapes"45 subtly woven into the presented narratives and offering their own stories and affects. The landscape is not only a material setting wherein things happen, but it also actively participates in structuring how they happen.

The tour through Whitney Plantation is spatially conducted, and this spatial materiality contributes extensively to the knowledge with which the visitors leave the site. The guided journey starts in the old African American church, which originally served as a place where the enslaved could find temporary relief from their tough work and a shelter from the intolerable

no. 5, 2016, p. 1-17; GOLAŃSKA, Dorota. Affective Connections. Towards A New Materialist Politics of Sympathy. New York and London: Rowman \& Littlefield Int., 2017.

${ }^{42}$ HARAWAY, Donna. Situated Knowledges... p. 585.

${ }^{43}$ See: BARAD, Karen. Posthumanist Performativity: Toward an Understanding of How Matter Comes to Matter. In: Signs: Journal of Women in Culture and Society, vol. 28, no. 3, 2003, p. 801-831 and BARAD, Karen. Meeting the Universe Halfway: Quantum Physics and the Entanglement of Matter and Meaning. Durham, NC: Duke University Press, 2007.

${ }^{44}$ BARAD, Karen. Meeting the Universe Halfway... p. 66.

${ }^{45}$ MODLIN, Arnold. E., ALDERMAN, Derek H., GENTRY, Glenn W. Tour Guides as Creators of Empathy... p. 5. 
Southern heat. A projection of a short movie aims to familiarise visitors with the history of the place, which was initially home to German immigrants (the Heidel family), and to inform them about the idea behind the current shape and purpose of the site. A series of full-sized terracotta statues of enslaved children (an artwork by Woodrow Nash, commissioned by the current owner of the plantation) are scattered around the church and the whole property, to offer visitors an opportunity for a more emotional (perhaps even empathetic ${ }^{46}$ ) engagement with the situation of the slaves. This corresponds with the design of the museum tickets, picturing one of the statues along with a quotation of a memory of a former slave, interviewed within the Works Progress Administration's Federal Writers' Project in the 1930s and encompassing mostly the accounts of people who experienced enslavement as children. The site also pays tribute to the memory of the enslaved children in other places. Most meaningfully, a separate memorial located on the plantation is dedicated to the memory of 2,200 children who died in slavery in Louisiana before they reached the age of three. Visitors are encouraged to pause there and honour the memory of these enslaved children. An encounter with the statues of children during the initial phase of the tour has an evocative effect. The material figures, of natural size, situated in direct proximity to the visitors produce a feeling of helplessness and fear stemming from the involuntary, almost automatic identification with the fate of the enslaved children from the past, deprived of the most serene period of their life and forced to work for the owner's family. Later on, during the rather brief tour of the big house, the guide depicts responsibilities of these young children connected to the maintenance of the house (e.g. cleaning) and caring for the master's family (e.g. preparing hot water for bathing). The testimonies of former slaves, made available to visitors at different points, evidence these children's exposure to violence, and also to violence perpetrated against their parents and other family members. This casts a shadow on the whole experience of visiting the site.

After leaving the church, visitors embark on a guided walk through the property, pausing at memorial sites and visiting the remaining infrastructure. The initial view with which visitors are confronted extends across the vast area of the landscape (Figure 1). The terrain of the Whitney Plantation, basked in light of the southern sun, looks exceptionally picturesque and groomed, with spacious lawns, beautiful trees and nice buildings (especially the big house). This picture seems to be neat and natural, offering the visitors a brisk yet relaxing bodily experience connected to the stunning gorgeousness of the space and the splendid weather conditions the caressing sunlight and sweeping southern heat, ideal for a slow walk. Yet, it must be kept in mind that landscapes are often fashioned with an intention to hide the real work that created them. This is a common strategy, adopted by most of the plantation museums, encouraging visitors to contemplate the beauty of their surroundings, sustaining the dominant romanticised and nostalgic portrayal of the American South. As Mitchell reminds us, "those who build the landscape are not the same as those who own the landscape" ${ }^{\text {" }}$. Realisation of this fact comes quickly in the course of the tour. The site provides visitors with a detailed account of the demanding unpaid work performed by the enslaved in the process of manufacturing the wealth of the plantation owners, as well as in taking care of the mansion they inhabited. The guide explains the arduous efforts invested in the cultivation of sugarcane and the production

\footnotetext{
${ }^{46}$ For elaboration of empathy in the context of plantation tourism, see: COOK, Matthew R. Counter-Narratives of Slavery in the Deep South: The Politics of Empathy Along and Beyond River Road. In: Journal of Heritage Tourism, vol. 11, no. 3, 2015, p. 290-308.

${ }^{47}$ MITCHELL, Don. Landscape. In: SIBLEY, David, JACKSNON, Peter, ATKINSON, David, WASHBOURNE, Neil (eds). Cultural Geography: A Critical Dictionary of Key Concepts. London and New York: Tauris, 2005, p. 51.
} 
of molasses, which guaranteed the prosperity of the plantation and assured a high quality of life for the master's family, translated into, among other things, the displayed soothing beauty of the property.

It is noteworthy that the depiction of the slaves' work in the fields is atypical for this kind of tourist attraction. Even though an increasing number of plantation heritage sites are tending toward incorporating some of the stories of the enslaved, they usually focus on those African Americans who were performing work in the house rather than in the fields. Usually, these people are referred to by the word "servant" rather than the term "slave", so as to mitigate the overall tone of the narrative and belittle the tremendous importance of slaves' work in the fields for both the property and the whole Southern economy. This, however, is not the

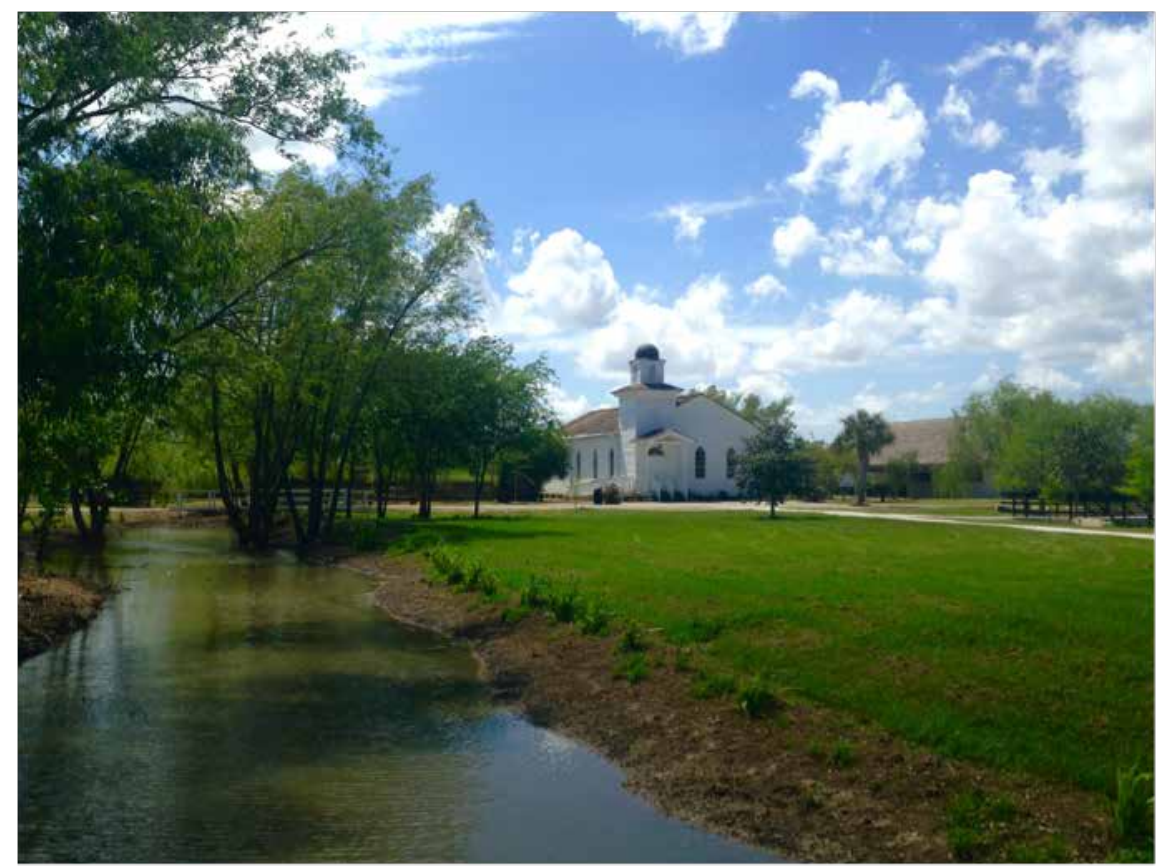

Figure 1: $A$ view of Whitney Plantation, Wallace, $L A$.

Picture taken by the author during a research visit in April 2015.

case at Whitney Plantation. Here, situated within the exquisite and generous scenery of the site, visitors are forced to realise the fact that the peaceful and comforting charm of the vast, luminous landscape of the plantation is far from innocent. They come to understand that it was produced in the heat of Louisiana's weather (nice for walkers but atrocious for field workers) by those who were never meant to benefit from it. The initial sensuous experience of the mythic Southern vista, seemingly embracing the body of the visitor, is brutalised by the sudden understanding of the circumstances in which the landscape originally emerged and was subsequently maintained. This comprehension hampers earlier innocuous contemplation and bodily pleasure, forcing reflection on the inequality and abuse ingrained in the plantation's life.

\section{The inhabitants}

The predominant part of the Whitney Plantation guided tour is devoted to visiting the slave cabins, overseers' houses and barns. These buildings are central to the visitors' learning 
experience. Most of the Southern plantation heritage sites in the region tend to avoid taking tourists to slave cabins, even when they are installed (preserved, reconstructed or replicated) on the plantation, leaving them occasionally to optional, self-guided visits. Small argues that in the vast majority of plantation tourist sites, slave cabins are not incorporated into the tourist narrative: "Although the mansions occupied by elite white plantation holders invariably garner most attention in heritage tourism, the slave cabins occupied by the majority of residents of the plantations provide insights into the institutionalisation of neglect". ${ }^{48}$ This testifies explicitly to whose lives seem to matter more, for both the heritage industry and the dominant (most powerful) groups of American society. Whitney Plantation acquaints its visitors with the details of the slaves' life, exposing their harsh living and working conditions. Here, the cabins are made the chief element of the guided tour; visitors are invited in, offering a bodily experience of the space inhabited in the past by the enslaved and providing details (including biographical ones) of individuals' lives and the socio-cultural practices in which they engaged. Most of the narrative, however, is devoted to the meticulous description of the unpaid work they were forced to perform, making this dimension of the past operations of the site a highly important aspect of the educational process. The guide explains that sugarcane was a demanding and dangerous crop to grow and process. The juice extracted from sugarcane had to be heated in a series of huge open kettles, a significant number of which are still present on the plantation (Figures 2 and 3). Slaves were responsible for pouring the juice from one kettle to another as it reduced. This resulted in many serious injuries and, occasionally, even deaths. Visitors can touch and hold the preserved tools that slaves used in the fields or for performing other tasks and imagine the harshness and severity of their work. By revealing the details of plantation life and confronting visitors with material artefacts utilised by enslaved workers in the past, Whitney Plantation underlines the crucial contribution of slave labour to the economy and wealth of the American South, paying attention to how this work was performed, by whom, and for whose benefit.

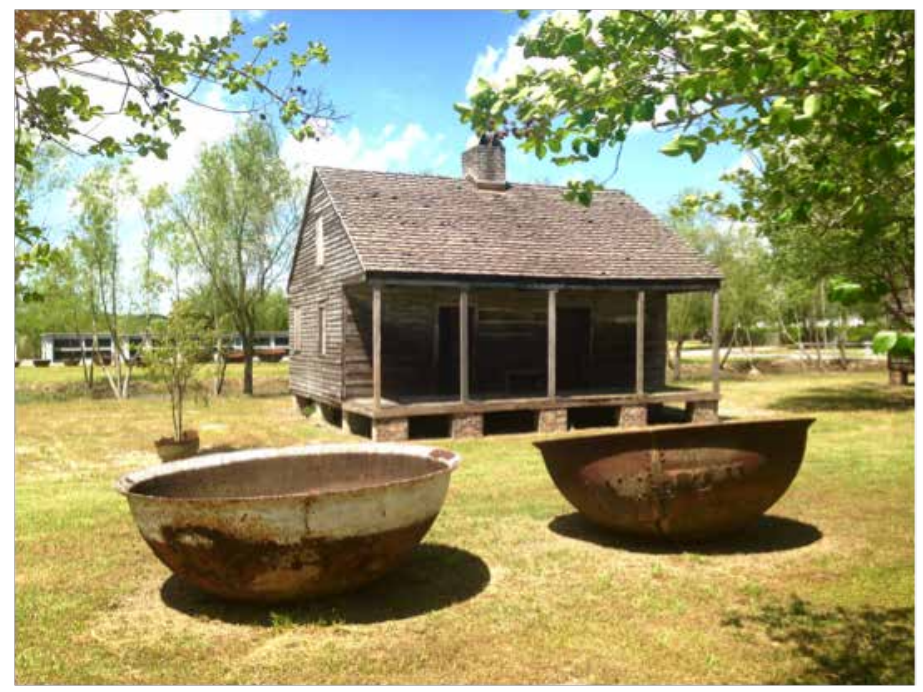

Figure 2: Slave cabins and kettles used in the production of sugar. Whitney Plantation, Wallace, LA.

Picture taken by the author during a research visit in April 2015.

${ }^{48}$ SMALL, Stephen. Still Back to the Big House... p. 405 
The tour of the big house is offered only as an experience complementing the earlier sightseeing of the slave cabins. Whitney Plantation pays attention to the hard work of slaves that was necessary to maintain the house and guarantee the prosperity of the property. This approach has little in common with typical strategies used in similar heritage sites where, as Carter, Butler and Alderman point out, "the principal and thinly veiled message embedded within ... plantation museum narratives is that the original white inhabitants of the plantation house were industrious people who lived elegant and honourable lives". ${ }^{49}$ As a rule, the emphasis on the white owners is also exemplified by focusing on the biographical details of their life, including tragic events such as those related to fatal illnesses and the loss of beloved

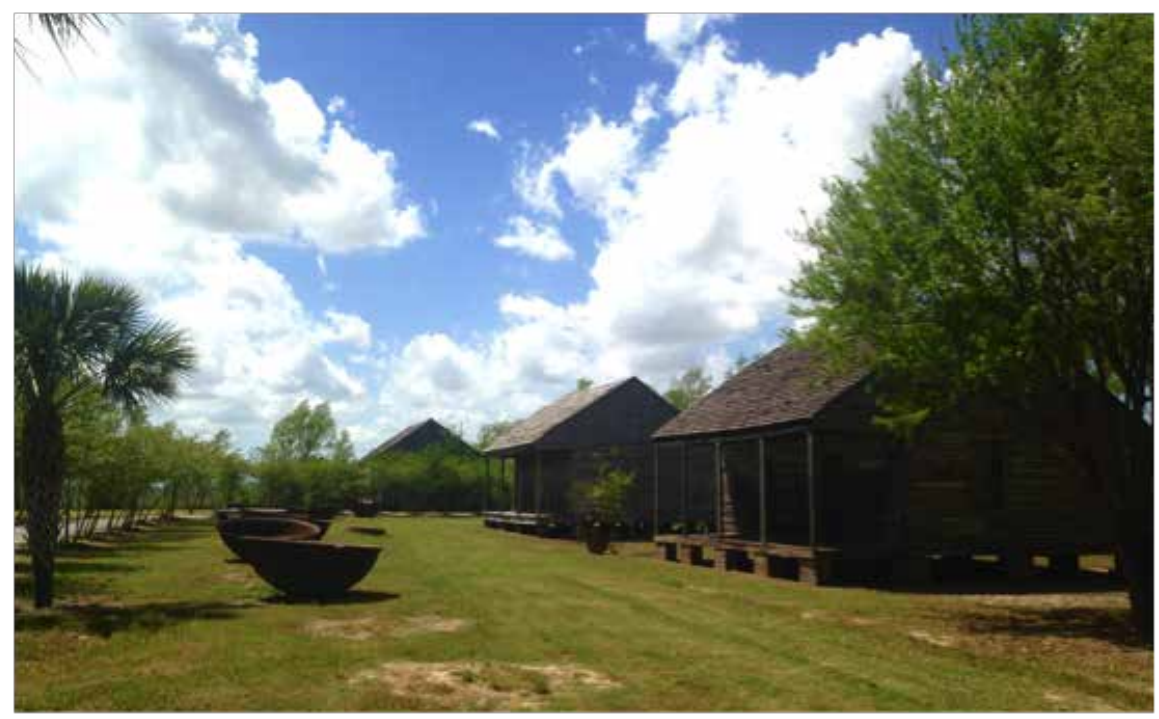

Figure 3: Slave cabins and kettles used in production of sugar. Whitney Plantation, Wallace, $L A$. Picture taken by the author during a research visit in April 2015.

children or other relatives of the master's family. Such narrative strategies remain in radical contrast with presentation of the experiences and biographies of the black inhabitants of the plantation. Most plantations do not mention the harsh and heart-breaking experience of African Americans, whose children were forcibly separated from them when they were sold to other plantations or when they died from untreated illnesses. None of them mention that the mortality rates among the enslaved were astounding. As Small underlines, "visitors hear little or nothing about the enslaved residents of the cabins in ways that individualise or humanise them (such as names, biographies, life experiences, cultural or religious practices, or their hopes, dreams, and aspirations)". ${ }^{50}$ At Whitney Plantation, the usual balance between the amount of attention given to the white and the black past inhabitants of the property are upturned. This approach is partly based on work of Ibrahima Seck, a member of the History Department of Chikh Anta Diop University (also known as the University of Dakar) in Senegal, who now serves as Head of Research at the analysed heritage site. Seck has conducted extensive investigations into cultural connections between West Africa and Louisiana, with the aim of

${ }^{49}$ CARTER, Perry L., BUTLER, David L., ALDERMAN, Derek, H. The House the Story Built... p. 550.

${ }^{50}$ SMALL, Stephen. Still Back to the Big House... p. 419. 
explaining patterns within the transatlantic slave trade. As a result of this research, more than 350 people whose enslaved labour contributed to the development of plantation have been identified by name, often "through legal records in which they were listed as assets of the property owner". ${ }^{51}$

The institution of slavery is presented as absolutely crucial to the development of the region and the individual slaves are given a proper place in the narrative offered to visitors. The bodily and performative strategies utilised in the material-semiotic educational process on site also facilitate the adoption of a slave-centric view and an understanding of the experience of the enslaved. The direct aesthetic encounter with the materiality structuring the plantation's life leaves impressions on visitors' bodies as they participate materially in the learning procedures. Discursive and corporeal means are employed to make it absolutely clear how radical inequalities structured the life of the region in the past, and how visible legacies of this violence remain today. Again, the educational process relies heavily on narrative-bodily techniques, turning visitors' bodies - through the facilitation of sensorial engagement with the objects and space - into active learning tools. The procedure assumes that the most effective educational means consist in encouraging visitors to experience an immediate sense of the site, rather than exclusively providing them with knowledge about it (where the latter approach demands some critical distance while the former rests on direct physical contact). The material and the semiotic combine with each other, making delineation of any clear boundaries between the narrative and the affective techniques impossible. The knowledge-generating experience takes the form of a material-semiotic entanglement.

\section{The violence}

Nowhere is the bodily experience of the visitors more explicitly employed in the learning process than when they are invited to go inside the rusted jail (Figures 4 and 5), located in the central part of the plantation, where insubordinate slaves were once kept. This constitutes one of the most intense affective encounters of the entire tour. It also, quite overtly, challenges the narrative of the benevolent masters typically evoked at plantation museums in the region. By offering bodily contact with this instrument of torture used to punish undesired behaviour, the museum openly breaks with this tendency to falsely represent the plantation owners - a fallacy that is predominant in popular culture and embedded in the memorial landscape of the region pointing instead to their cruel treatment of the slaves. This is complemented with a depiction of other means of torture and punishments used by the slaveholders to exert their power over the enslaved and force them into obedience. The guide describes, for instance, the procedure of crippling slaves who attempted to escape by cutting their hamstrings. This direct exposure to the means of violence used against the enslaved helps visitors to approach the plantation through the eyes of its black inhabitants. Interestingly, the visitors first see the big house when they are inside the jail, so the view is interrupted by bars from behind which they can visually appraise the architecturally stunning property of the masters, into which the field slaves were not allowed. Once inside the jail (entering the cage is presented as an optional activity, yet strongly encouraged by the guide), the visitors are meant to experience the grim feeling of helplessness and misery. This is one of the most meaningful moments of the plantation tour:

${ }^{51}$ CARFAGNO, Jacalyn. Well-fed, Happy Slaves? Go Inside the Old South Narrative and See For Yourself. Lexington Herald Leader. 16 August 2019, https://www.kentucky.com/living/travel/article232845142.html, accessed 16 February 2020. 


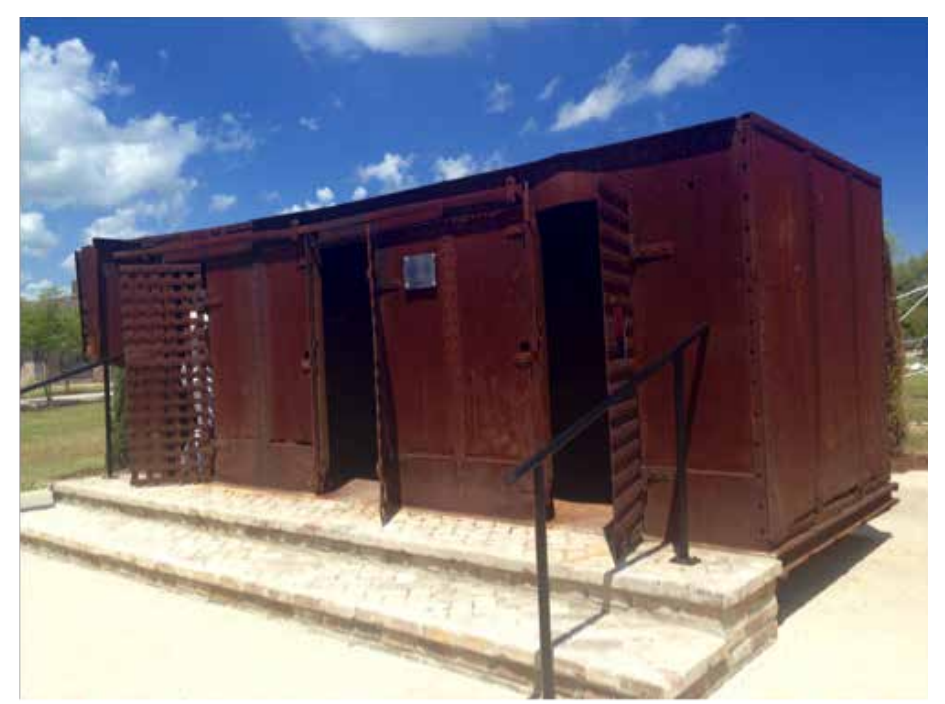

Figure 4: The jail, Whitney Plantation, Wallace, LA.

Picture taken by the author during a research visit in April 2015.

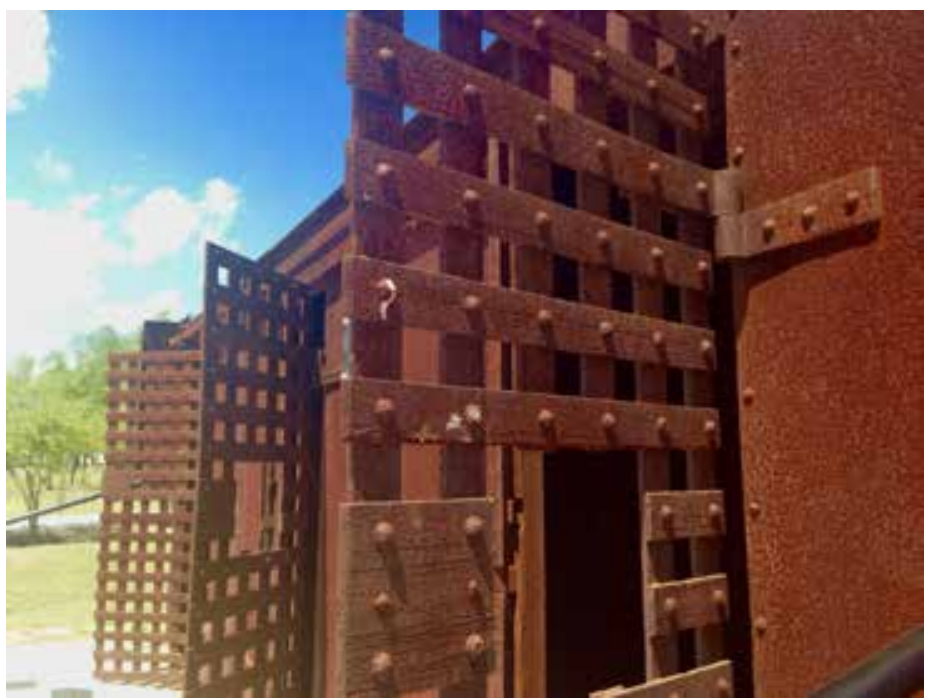

Figure 5: The jail, Whitney Plantation, Wallace, LA.

Picture taken by the author during a research visit in April 2015.

the material experience of being confined in a cage, whose walls are heated by the burning sun, produces an overwhelming feeling of entrapment, defencelessness, vulnerability and humiliation directly inscribed on the visitor's body. These bodily sensations are paralyzing and nauseating, triggering painful reflection on the devastating impact of institutionalised forms of violence on the mind and body of the enslaved.

The merciless cruelty of the system of enslavement is also evoked through another memorial place, situated within the Whitney Plantation to pay tribute to the memory of the slaves who were murdered for their involvement in the largest slave revolt in the American South, which erupted in January 1811 on the German Coast of Louisiana. In its aftermath, a great number of slaves were condemned to death and executed by beheading. The heads of those killed 
were planted on poles and exposed to the public to make it clear to other slaves what would happen if they rebelled against their masters. The memorial, created by Woodrow Nash, makes use of 63 ceramic heads mounted on steel rods and installed around the pond. As Carfagno explains, "cloths are tied around the heads in February when, each year, the ground is blessed. They represent crowns for the warriors who fought in the revolt". ${ }^{2}$ Apart from serving as a commemorative site, the memorial is meant to help visitors to appreciate the harsh cruelty of the (legal) system of slavery and the unthinkably dehumanising treatment of the enslaved. Pausing at this exceptional and devastating memorial fuels reflection on the highly problematic and extremely vehement nature of the structure of abuse and violence on which the wealth of the American South was built. The objectifying attitude adopted by the white majority toward African Americans is also demonstrated on a commemorative plaque listing all the slaves who inhabited the Whitney Plantation alongside the price for which each of them was purchased.

The nature of the material-semiotic experience, in which the visitors engage bodily and intellectually when entering the jail, is revealing. It rests on the idea of inviting a kind of empathetic identification - felt bodily - with those brutalised by the oppressive institutionalised system of violence, so often presented via the paternalistic narratives that pervade the American heritage industry as well as teaching programs. The learning process in which visitors participate at Whitney Plantation rests on their profound, sensorial involvement with the site, which leaves memorable bodily-intellectual traces, prompting the processes of generating meaningful knowledge and recollections.

\section{The slave trade}

Since a new materialist understanding of knowledge production focuses on the complex entanglements of the material and the semiotic, situating the learning experience offered to visitors in the broader political context further enhances understanding of the troubled history of American slavery. Differently from other plantation museums scattered over the region, Whitney Plantation aims to connect the story of the individuals who once inhabited the site to broader historical and socio-cultural processes. In its self-guided section, the Plantation offers an overview of the history of the transatlantic slave trade, from fifteenth-century Portuguese slavers to the international structure of human trafficking in the nineteenth century. It focuses on the scale of the phenomenon and lists the main countries involved in this violent procedure, with Portugal and Brazil being the most significant traders. Visitors are informed that most of the slaves came from West Central Africa, and that 2.5 million of them were sold to the US. The role of slavery, not only in boosting production on Southern plantations and contributing to the wealth of the owners, but also in fuelling much of the world's economy, is made evident. This remains in accord with recent scholarship exploring these issues. Baptist, for instance, underlines the fact that both the system of transatlantic African slave trade and enslaved labour itself have been absolutely foundational to the rapid development of North American capitalism, rather than being an aberration from it. ${ }^{53}$ Western economy and the affluence of white population in the antebellum American South relied completely on the institution of legalised violence against African Americans. Presenting the situation in this way sheds light on the fact that racist practices (including slavery) have, as Goldberg observes, been intersecting

\footnotetext{
${ }^{52}$ CARFAGNO, Jacalyn. Well-fed, Happy Slaves?...

${ }^{53}$ BAPTIST, Edward E. The Half Has Never Been Told: Slavery and the Making of American Capitalism. New York: Basic Books, 2014.
} 
with liberal economic approaches, paving the way for the establishment of the modern nation state. ${ }^{54}$ As Berlin points out, "The American economy was founded upon the production of slave-grown crops, the great stables of tobacco, rice, sugar, and finally cotton, which slave owners sold on the international market to bring capital into the colonies and then the young Republic." He adds, "The capital eventually funded the creation of an infrastructure upon which rests three centuries of American economic success". ${ }^{5}$ The wealth accumulated by Southern slave owners helped them secure access to political power and, subsequently, shape the dominant American values that pervade contemporary political culture. Such views do justice to the forced African American contribution to the establishment of the new state and its rapid growth, an input rarely acknowledged by any other memorial institution and largely omitted in educational programs.

\section{Fragmented memory: concluding remarks}

The analysis of the politics of memory and, especially, of whose interpretation of the past prevails, illuminates more general social conflicts and tensions. Sadly, a great majority of tourist sites located in the American South have adopted a white-centric perspective, marginalising the history and heritage of African American population and neglecting their contribution to the development of America's prosperous economy. Even though undoubtedly central to the growth of capitalism, the institution of slavery is seen as a rather shameful part of American history and remains an under-articulated trope of popular narratives depicting the South and its legacies. This translates into a tacit denial of the crucial role of African Americans in building American culture and prosperity, as manifested in the biased construction of the national memorial landscape. Certainly, this landscape is itself shaped by the most powerful strata of the population and reflects their interpretations of the past, which subsequently gain the status of the most authoritative and taken-for-granted knowledge. The recent appearance of heritage sites adopting a different perspective is a symptom of the tendency to offer a more tangled and, in fact, a fairer view of national history with its traumas, atrocities and crimes. This difficult heritage is undoubtedly dissonant and, as such, it has a thoroughly emotional character and fragmented nature.

As mentioned earlier, Vinitzky-Seroussin differentiates between "fragmented" and "multivocal" commemoration strategies. ${ }^{56}$ The latter assumes that a given society or group demonstrates some ability to create a middle ground for conflicting memories and interpretations of the past. Memorial sites adopting a multivocal format aim to convey ambivalence, rather than conceal it, so that divergent audiences can share the same commemorative space, although for different reasons. This could also apply, I argue, to heritage sites, which do not necessarily display a memorial character (like plantation museums). Fragmented memory sites, as VinitzkySeroussin explains, do not attempt to find a compromise in their understanding of past events, but rather employ discourses aimed at specific type of audience. With the appearance of heritage institutions offering a counter-narrative to the system of slavery, as well as in the context of the

\footnotetext{
${ }^{54}$ GOLDBERG, David Theo. The Racial State. Malden, MA and London: Wiley Blackwell, 2001.

${ }_{5}$ BERLIN, Ira. Coming to Terms With Slavery in Twenty-First-Century America. In: HORTON James O., HORTON, Lois E. Horton (eds). Slavery and Public History: The Tough Stuff of American Memory. New York: The New Press, 2006, p. 2. See also: BERLIN, Ira. Many Thousands Gone: The First Two Centuries of Slavery in North America. Cambridge, MA: The Belknap Press, 1998 and BERLIN, Ira. American Slavery in History and Memory and the Search for Social Justice. In: The Journal of American History, vol. 90, no. 4, 2004, p. 1251-1268.

${ }^{56}$ VINITZKY-SEROUSSI, Vered. Commemorating a Difficult Past... p. 31-32.
} 
(albeit still marginal) incorporation of the history of the enslaved within a growing number of well-established plantation museums in the American South, the overall memorial landscape of this region seems to be shifting toward multivocality. Yet, a closer examination of the particular sites, including this article's case study of Whitney Plantation, leads to the conclusion that this landscape remains steeped in fragmentation, with different sites offering narratives and experiences tailored to different kinds of visitors. This might produce a false impression that the stories of the plantation owners and those of the enslaved remain somewhat unrelated to each other. Certainly, institutions such as the Whitney Plantation are unquestionably much needed within the highly unbalanced panorama of heritage sites in the American South. But further efforts to include more unprejudiced and unbiased accounts of the enslavement must be encouraged across the huge number of plantation heritage sites, bearing in mind that they serve as popular destinations for tourists and attract thousands of visitors yearly.

The new materialist approach, which focuses on the complex entanglement of the material and the semiotic in the processes of knowledge production, enables a more complete understanding of how knowledge about the past emerges at heritage sites. Obviously, it applies to both white-centric and slave-centric strategies of engaging visitors in learning experiences. However, taking into consideration the material character of discriminatory practices, as well as of trauma itself, the bodily-narrative techniques utilised to familiarise visitors with the painful experiences connected to the historical system of enslavement seem to offer a good analytical material for figuring out not only what knowledges are produced but also, importantly, how they emerge. This remains of particular salience, taking into account the social dimension of educational processes enacted on heritage sites and the continually present legacies of violence pervading the mnemonic landscape of the American South.

\section{References}

ADAMS, Jessica (1999). Local Color. The Southern Plantation in Popular Culture. In: Cultural Critiques, vol. 42, p. 163-187. ISSN 1460-2458.

ALDERMAN, Derek H., INWOOD, Joshua F. (2013). Landscapes of Memory and Socially Just Futures. In: SCHEIN, Richard, WINDERS, Jamie, JOHNSON, Juala (eds). A New Companion to Cultural Geography. Chichester: Wiley Blackwell, p. 186-197. ISBN 9780470655597.

ALDERMAN, Derek H., MODLIN, E. Arnold (2008). (In)visibility of the Enslaved within Online Plantation Tourism Marketing: A Textual Analysis of North Carolina Websites. In: Journal of Travel and Tourism Marketing, vol. 25, no. 3-4, p. 265-281. ISSN 1540-7306.

ALDERMAN, Derek H., MODLIN, E. Arnold (2013). Southern Hospitality and the Politics of African American Belonging: An Analysis of North Carolina Tourism Brochure Photographs. In: Journal of Cultural Geography, vol. 30, no. 1, p. 6-31. ISSN 1940-6320.

ALDERMAN, Derek H., MODLIN E. Arnold (2015). On the Political Utterances of Plantation Tourists: Vocalizing the Memory of Slavery on River Road. In: Journal of Heritage Tourism, vol. 11, no. 3, p. 275-289. ISSN 1747-6631.

ALDERMAN, Derek H. - BUTLER, David L. - HANNA, Stephen P. (2015). Memory, Slavery, and Plantation Museums: The River Road Project. In: Journal of Heritage Tourism, vol. 11, no. 3, p. 209-218. ISSN 1747-6631. 
D. Golańska: Against the "Moonlight and Magnolia" myth of the American South...

ALDERMAN, Derek, CAMPBELL, Rachel (2008). Symbolic Excavation and the Artifact Politics of Remembering Slavery in the American South. In: Southeastern Geographer, vol. 48, no. 3, p. 338-353. ISSN 1549-6929.

ALONSO, Anam M. (1988). The Effects of Truth: Re-presentation of the Past and the Imagining of Community. In: Journal of Historical Sociology, vol. 1, no. 1, p. 33-58. ISSN 1467-6443.

AMSDEN, David (2015). Building the First Slavery Museum in America. In: New York Times Magazine, 26 February 2015, http://mobile.nytimes.com/2015/03/01/magazine/builitngthe-first-slave-museum-in-america.html, accessed 21 February 2020.

BAPTIST, Edward E. (2014). The Half Has Never Been Told: Slavery and the Making of American Capitalism. New York, NY: Basic Books. ISBN 9780465049660.

BARAD, Karen (2003). Posthumanist Performativity: Toward an Understanding of How Matter Comes to Matter. In: Signs: Journal of Women in Culture and Society, vol. 28, no. 3, p. 801-831. ISSN 0097-9740.

BARAD, Karen (2007). Meeting the Universe Halfway: Quantum Physics and the Entanglement of Matter and Meaning. Durham, NC: Duke University Press. ISBN 9780822339175.

BENJAMIN, Stephanie, ALDERMAN, Derek H. (2018). Performing a Different Narrative: Museum Theatre and the Memory-work of Producing and Managing Slavery Heritage at Southern Plantation Museums. In: International Journal of Heritage Studies, vol. 24, no. 3, p. 270-282. ISSN 1470-3610.

BERLIN, Ira (1998). Many Thousands Gone: The First Two Centuries of Slavery in North America. Cambridge, MA: The Belknap Press. ISBN 9780674002111.

BERLIN, Ira (2004). American Slavery in History and Memory and the Search for Social Justice. In: The Journal of American History, vol. 90, no. 4, p. 1251-1268. ISSN 0021-8723

BERLIN, Ira (2006). Coming to Terms with Slavery in Twenty-First-Century America. In: HORTON James O., HORTON, Lois E. Horton (eds). Slavery and Public History: The Tough Stuff of American Memory. New York, NY: The New Press, p. 1-17. ISBN 9780807859162.

BEST, Mechelle N., PHULGENCE, Winston F. (2013). Interpretation of Contested Heritage at an Attraction in St. Lucia. In: Journal of Heritage Tourism, vol. 8, no. 1, p. 21-35. ISSN 1747-6631.

BOIVIN, Nicole (2008). Material Cultures, Material Minds: The Impact of Things on Human Thought, Society, and Evolution. Cambridge: Cambridge University Press. ISBN 9780521176132.

BRUNDAGE, Fitshugh W. (2006). The Southern Past: A Clash of Race and Memory. Cambridge, MA: Harvard University Press. ISBN 9780674027213.

BUTLER, David L. (2001). Whitewashing Plantations: The Commodification and Social Creation of a Slave-free Antebellum South. In: International Journal of Hospitality, vol. 2, no. 3/4, p. 159-171. ISSN 1525-6499.

BUZINDE, Christine N. (2010). Discursive Construction of the Plantation Past within a Travel Guidebook. In: Journal of Heritage Tourism, vol. 5, no. 3, p. 219-235. ISSN 1747-6631.

BUZINDE, Christine N., OSAGIE, Iyunolu F. (2011). Slavery Heritage Representations, Cultural Citizenship, and Judicial Politics in America. In: Journal Historical Geography, vol. 39, p. 41-64. ISSN 0305-7488.

BUZINDE, Christine N., SANTOS, Carla A. (2009). Interpreting Slavery Tourism. In: Annals of Tourism Research, vol. 36, no. 3, p. 439-458. ISSN 0160-7383. 
BUZINDE, Christine (2007). Representational Politics of Plantation Heritage: The Contemporary Plantation as a Social Imaginary. In: MCCARTHY, Cameron et al. (eds). Globalizing Cultural Studies: Ethnographic Interventions in Theory, Method and Policy. New York, NY: Peter Lang, p. 229-252. ISBN 9780820486833.

CARFAGNO, Jacalyn 2019. Well-fed, Happy Slaves? Go Inside the Old South Narrative and See for Yourself. In: Lexington Herald Leader. 16 August 2019, https://www.kentucky.com/ living/travel/article232845142.html, accessed 16 February 2020.

CARTER, Perry L., BUTLER, David L., ALDERMAN, Derek, H. (2014). The House the Story Built: The Place of Slavery in Plantation Museum Narratives. In: The Professional Geographer, vol. 66, no. 4, p. 547-557. ISSN 1467-9272.

COOK, Matthew R. (2015). Counter-narratives of Slavery in the Deep South: The Politics of Empathy Along and Beyond River Road. In: Journal of Heritage Tourism, vol. 11, no. 3, p. 290-308. ISSN 1747-6631.

DANN, Graham M. S. - SEATON, A. V. (2001). Slavery, Contested Heritage and Thanatourism. In: International Journal of Hospitality \& Tourism Administration, vol. 2, no. 3/4, p. 1-29. ISSN 1525-6499.

DANN, Graham M. S., POTTER, Robert B. (2001). Supplanting the Planters: Hawking Heritage in Barbados. In International Journal of Hospitality \& Tourism Administration, vol. 2, no. 3/4, p. 51-84. ISSN 1525-6499.

DAVIS, Patricia (2013). Memoryscapes in Transition: Black History Museum, New South Narratives, and Urban Regeneration. In: Southern Communication Journal, vol. 78, no. 2, p. 107-127. ISSN 1930-3203.

DENNIS, Benjamin G., DENNIS, Anita K. (2008). Slaves to Racism: An Unbroken Chain from America to Liberia. New York, NY: Algora Publishing. ISBN 9780875866574.

DUBOIS, W. E. Burghardt (1935/2014). Black Reconstruction: An Essay Toward a History of the Part Which Black Folk Played in the Attempt to Reconstruct Democracy in America, 1860-1880. Oxford: Oxford University Press. ISBN 0199385653.

EICHSTEDT, Jennifer, SMALL, Stephen (2002). Representations of Slavery: Race and Ideology in Southern Plantation Museums. Washington, DC: Smithsonian Institute Press. ISBN 9781588340962.

FORBES, Candace, ALDERMAN, Derek H., BUTLER, David L. (2018). Tourist Plantation Owners and Slavery: A Complex Relationship. In: Current Issues in Tourism, vol. 21, no. 15, p. 1743-1760. ISSN 1747-7603.

FOREST, Benjamin, JOHNSON, Juliet (2002). Unravelling the Threads of History: Soviet-Era Monuments and Post-Soviet National Identity in Moscow. In: Annals of the Association of American Geographers, vol. 92, no. 3, p. 524-547. ISSN 2469-4460.

GIOVANET'TI, Jorge L. (2006). Grounds of Race: Slavery, Racism and the Plantation in the Caribbean. In: Latin American and Caribbean Ethnic Studies, vol. 1, no. 1, p. 5-36. ISSN 17442230.

GOLAŃSKA, Dorota (2015). Affective Spaces, Sensuous Engagements: In Quest of a Synaesthetic Approach to "Dark Memorials". In: International Journal of Heritage Studies, vol. 21, no. 8, p. 773-790. ISSN 1470-3610.

GOLAŃSKA, Dorota (2016). Terrifying Pleasures: In Quest of an Affirmative Approach to "Dark" Installation Art. In: Liminalities: A Journal of Performance Studies, vol. 12, no. 5, p. 1-17. ISSN 1557-2935. 
D. Golańska: Against the "Moonlight and Magnolia" myth of the American South...

GOLAŃSKA, Dorota (2017). Affective Connections. Towards A New Materialist Politics of Sympathy. New York and London: Rowman \& Littlefield Int. ISBN 9781783489695.

GOLDBERG, David Theo. (2001). The Racial State. Malden, MA and London: Wiley Blackwell. ISBN 9780631199212.

GREENE, Mark A. (2003-2004). The Messy Business of Remembering: History, Memory, and Archives. In: Archival Issues, vol. 28, no. 2, p. 95-103. ISSN 1992-2016.

HALBWACHS, Maurice (1992). On Collective Memory. Chicago, IL: University of Chicago Press. ISBN 9780226115962.

HANDLER, Richard - GABLE, Eric (1997). The New History in an Old Museum: Creating the Past at Colonial Williamsburg. Durham, NC and London: Duke University Pres. ISBN 9780822319740.

HANNA, Stephen P., POTTER, Amy E., MODLIN E. Arnold, CARTER, Perry, BUTLER, David L. (eds) (2015). Social Memory and Heritage Tourism Methodologies. New York: Routledge. ISBN 9780415745383.

HARAWAY, Donna (1988). Situated Knowledges. The Science Question in Feminism and the Privilege of Partial Perspective. In: Feminist Studies, vol. 14, no. 3, p. 575-599. ISSN 00463663.

HOELSCHER, Steven (2003). Making Place, Making Race: Performances of Whiteness in the Jim Crow South. In: Annals of the Association of American Geographers, vol. 93, no. 3, p. 657-686. ISSN 2469-4460.

HOELSCHER, Steven (2006). The White-Pillared Past: Landscapes of Memory and Race in the American South. In: SCHEIN, Richard (ed). Landscape and Race in the United States. New York: Routledge, p. 39-72. ISBN 9780415949941.

INWOOD, Joshua F.J. (2010). Sweet Auburn: Constructing Atlanta's Auburn Avenue as a Heritage Tourist Destination. In: Urban Geography, vol. 31, no. 5, p. 573-594. ISSN 19382847.

JACKSON, Antoinette T. (2011). Shattering Slave Life Portrayals: Uncovering Subjugated Knowledge in US Plantation Sites in South Carolina and Florida. In: American Anthropologist, vol. 113, no. 3, p. 448-462. ISSN 1548-1433.

JACKSON, Antoinette T. (2016). Speaking for the Enslaved: Heritage Interpretation at Antebellum Plantation Sites. New York: Routledge. ISBN 9781598745498.

LOGAN, William, REEVES, Keir (2009). Introduction: Remembering Places of Pain and Shame. In: LOGAN (ed). Places of Pain and Shame: Dealing with "Difficult Heritage". London: Routledge, p. 1-14. ISBN 9780415454506.

MACDONALD, Sharon (2006). Undesirable Heritage: Fascist Material Culture and Historical Consciousness in Nuremberg. In: International Journal of Heritage Studies, vol. 12, no. 1, p. 9-28. ISSN 1470-3610.

MACDONALD, Sharon. 2013. Memorylands. Heritage and Identity in Europe Today. New York: Routledge. ISBN 9780415453349.

MCPHERSON, Tara (2003). Reconstructing Dixie: Race, Gender, and Nostalgia in the Imagined South. Durham, NC: Duke University Press. ISBN 9780822330400.

MITCHELL, Don (2005). Landscape. In: SIBLEY, David, JACKSON, Peter, ATKINSON, David, WASHBOURNE, Neil (eds). Cultural Geography: A Critical Dictionary of Key Concepts. London and New York: Tauris, p. 49-56. ISBN 9781860647024. 
MODLIN, Arnold E. (2008). Tales Told on the Tour: Mythic Representations of Slavery by Docents at North Carolina Plantation Museums. In: Southeastern Geographer, vol. 48, no. 3, p. 265-287. ISSN 1549-6929.

MODLIN, Arnold. E., ALDERMAN, Derek H., GENTRY, Glenn W. (2011). Tour Guides as Creators of Empathy: The Role of Affective Inequality in Marginalizing the Enslaved at Plantation House Museums. In: Tourist Studies, vol. 11, no. 1, p. 3-19. ISSN 1468-7976.

NEAL, Arthur G. (1998). National Trauma and Collective Memory. Armonk, NY: M. E. Sharpe. ISBN 9780765602879.

OOI, Ceng-Seng (2002). Persuasive Histories: Decentring, Recentring and the Emotional Crafting of the Past. In: Journal of Organizational Change, vol. 15, no. 6, p. 606-620. ISSN 0953-4814.

POIROT, Kristan, WATSON, Shevaun E. (2015). Memories of Freedom and White Resilience: Place, Tourism, and Urban Slavery. In: Rhetoric Society Quarterly, vol. 45, no. 2, p. 91-116. ISSN 0277-3945.

RIDER, Polly (2019). A History of the Whitney Plantation, America's First Slavery Museum. In: The Culture Trip, December 2019, https://theculturetrip.com/north-america/articles/ whitney-plantation-america-s-first-slavery-museum/, accessed 16 February 2020.

SCHWARTZ, Barry (1996). Memory as a Cultural System: Abraham Lincoln and World War II. In: American Sociological Review, vol. 61, no. 5, p. 908-927. ISSN 0003-1224.

SMALL, Stephen (2013). Still Back of the Big House: Slave Cabins and Slavery in Southern Heritage Tourism. In: Tourism Geographies, vol. 15, no. 3, p. 405-423. ISSN 1470-1340.

STURKEN, Marita (1997). Tangled Memories. Berkeley, CA: University of California Press. ISBN 9780520206205.

SUNDQUIST, Eric J. (1993). To Wake the Nation: Race in the Making of American Literature. Cambridge, MA: Harvard University Press. ISBN 067489331X.

THOMPSON, Craig, TIAN, Kelly (2008). Reconstructing the South: How Commercial Myths Compete for Identity Value Through the Ideological Shaping of Popular Memories and Counter-Memories. In: Journal of Consumer Research, vol. 34, no. 5, p. 595-613. ISSN $1537-$ 5277.

TUNBRIDGE, J. E., ASHWORTH, G. J. (1996). Dissonant Heritage. The Management of the Past as a Resource in Conflict. Chichester: Wiley. ISBN 9780471948872.

UZZELL, David L., BALLANTYNE, Roy (1998). Heritage that Hurts: Interpretation in a Postmodern World. In: UZZELL, David L., BALLANTYNE, Roy (eds). Contemporary Issues in Heritage and Environmental Interpretation. London: The Stationery Office, p. 152-171. ISBN 97801129005721

VINITZKY-SEROUSSI, Vered (2002). Commemorating a Difficult Past: Yitzhak Rabin's Memorials. In: American Sociological Review, vol. 67, no. 1, p. 30-52. ISSN 0003-1224.

WAGNER-PACIFICI, R. - SCHWARTZ, Barry (1991). The Vietnam Veterans Memorial: Commemorating a difficult past. In: American Journal of Sociology, vol. 97, no. 2, p. 376-420. ISSN 0002-9602.

YANKHOLMES, Aaron, MCKERCHER, Bob (2015). Rethinking Slavery Heritage Tourism. In: Journal of Heritage Tourism, vol. 10, no. 3, p. 233-247. ISSN 1747-6631.

YANKHOLMES, Aaron, MCKERCHER, Bob (2015). Understanding Visitors to Slavery Heritage Sites in Ghana. In: Tourism Management, vol. 51, no. C, p. 22-32. ISSN 0261-5177. 
YUHL, Stephanie E. (2005). A Golden Haze of Memory: The Making of Historic Charleston. Chapel Hill, NC: University of North Carolina Press. ISBN 9780807855997.

ZAKOS, Katharine P. (2015). Truth is Marching On: The Lasershow Spectacular at the Stone Mountain Park Confederate Memorial and the Changing Narratives of History. In: Journal of Heritage Tourism, vol. 10, no. 3, p. 280-295. ISSN 1747-6631. 